\title{
The Effectiveness of Thematic Textbook Based on Local Wisdom on Cooperation Character of First Grade Students of Primary School
}

\author{
Amaliyah Ulfah", Siwi Purwanti \\ Primary School Education Program, Ahmad Dahlan University, Indonesia
}

Received March 31, 2020; Revised June 2, 2020; Accepted June 24, 2020

Copyright $(2020$ by authors, all rights reserved. Authors agree that this article remains permanently open access under the terms of the Creative Commons Attribution License 4.0 International License

\begin{abstract}
This study aims to determine the effectiveness of thematic textbooks based on local wisdom on the cooperation character in grade 1 elementary school students. The study used was Quasi Experiment with the Pretest-Posttest Group design. The subjects of this study were grade 1 students of primary school. The control group was class $1 \mathrm{~B}$ with a total of 26 students, and the experimental group was class $1 \mathrm{~A}$ with 27 students. The data was collected through observation and analyzed using parametric statistical data. The hypothesis test used Independent Sample T test. The results of the study show that the implementation of thematic textbooks based on local wisdom is effective towards students' cooperation character. In addition, the use of textbooks based on local wisdom in the experimental class increases students' character of cooperation in all indicators, such as participating actively in group discussions, receiving opinions from friends in discussions, creating an atmosphere that is familiar in group discussions, supporting friends who give opinions, and giving motivation to less active group members.
\end{abstract}

Keywords Local Wisdom, Cooperation Character, Thematic Learning, Textbook

\section{Introduction}

Local wisdom is a value system or living behavior of local communities in interacting with the environment in which they live wisely [1]. The values can be interpreted as written or unwritten inherent rules for a long time. Local wisdom refers to the knowledge that comes from the community's experiences and the accumulation of local knowledge [2]. Parents, hometown and motherland, language, religion, culture, social system, nation and state are sources of local wisdom and should be used as a basis for shaping children's personality [3]. Various kinds of local wisdom are potential for the development of education based on local wisdom. Therefore, education needs to immediately design, determine the most appropriate model for seeding local wisdom.

Local wisdom contains character values that can be developed for character education. Local wisdom can be the source for humanist character education [4]. Local wisdom-based education teaches students to always contetualize learning. It becomes the capital of noble character formation, that is, the character of the nation which always acts with awareness, self-primacy, and self-control which is adaptive to all situations.

Character education is an effort to help someone to be able to understand, pay attention and do ethical values well [5]. The formation of good character, especially in students can be seen from the way of they think and behave in environments such as family, school and community. Environmental factors provide a significant positive influence on character formation [6]. Good character is also not automatically possessed. Good character is not automatically formed; it is developed over time through a sustained process of teaching, exemplifying, learning, and practicing [7].

Character education should be implemented since the most basic level of education [8]. States character education in schools leads to the strengthening and developing children's behavior based on the values referred to by the school [9]. Effective character education requires a strategy that includes exemplification, disciplined cultivation, habituation, creation of conducive atmosphere, integration and internalization, and coaching. Exemplification has a very large contribution in character education. Teacher's examples in various activities will be reflections for students; this example emphasizes aspects 
of behavior in the form of real actions. Therefore, through the attitudes and behaviors carried out by the teacher, students will imitate or get an idea that of the good behavior [10].

Values in character education include religion, discipline, honesty, and cooperation that can be integrated into learning activities. Furthermore, teaching discipline, habituation and teachers' continuous guidance can make students have good character. Coaching will also be successful through teachers' and parents' support. The result of the formation of character education is also important on the future of a nation, because tomorrow's leaders are students who study in school now. The outcome of character education has always been encouraging, solidly, and continually preparing the leaders tomorrow [11]. This study focuses on cooperation character because it is strongly needed individuals, especially in terms of social relations [12]. Indicators of the cooperation character are 1) giving opinions in teamwork; 2) giving and listening to opinions in class discussions; 3 ) participating in social and cultural activities [13].

Based on observations, it showed that the characters of the students vary. In class $1 \mathrm{~A}$ with 27 students, the researcher obtained the following information, (1) students often arrived late in school (2) students were less active during the learning process (3) students were lack of confidence in learning activities. That situation was almost the same with class $1 \mathrm{~B}$, with 26 students, there were still threes and even more students who arrived late in school and students' self-confidence was still low. In addition, based on interviews with the teachers in grade $1 \mathrm{~A}$ and $1 \mathrm{~B}$ related to teaching instruments, the following information is obtained: (1) Teachers did not always develop all components of learning instruments, (2) Teachers did not integrate learning instruments that integrate character values, (3) Teachers did not integrate learning instruments based on local wisdom, and (4) Students had no idea about local wisdom. While, textbooks are one of the teaching materials serve as a means of supporting learning activities [14].

Then, it was further elaborated with the results of interviews with grade 1 teachers at Elementary School. The characteristics of students in Elementary School varied because they came from different regions. Furthermore, many of the students had ignorant parents. Based on the explanation, it could be seen that students' character values were still low, and the local wisdom which should be introduced to students was not optimal. In addition, the teachers were still lack of understanding regarding the value of character and local wisdom. It is very important for teachers to provide character education reinforcement through local wisdom so that students can recognize their environment [15]. Efforts that can be made to build character based on local wisdom in schools are through thematic learning.

Thematic learning is an integrated learning model that uses themes to link several subjects to provide meaningful experiences to students [16]. Thematic learning has several characteristics, they are: 1) Student centered, 2) Providing direct experience, 3) Unclear shift beetween subjects, 4) Presenting concepts from various subjects in a learning process, 5 ) Flexible 6) Learning outcomes in accordance with the interests and needs of students, and 7) Using the principle of learning while playing and fun.

Thematic learning is learning that integrates various competencies as outlined in the subjects into one theme. Thematic learning can be interpreted as learning activities with integration of materials of several subjects in one topic of discussion. Besides that, thematic learning provide opportunities for integrated learning that emphasizes more on student participation and learning involvement. Thematic learning has a very important role in increasing students' attention, activities, and understanding of the materials. Integration of character education based on local wisdom in the learning process through subjects is very important for students' readiness to apply character values in the environment [17]. In a study thematic learning beneficially affects students' character [18]. Based on the previous discussion, the researcher applied local wisdom-based thematic textbooks, particularly on the cooperation character with students, because at present teaching materials used by teachers have not fully integrated character values and are not based on local wisdom. The product developed in the previous study has only been validated by experts. Therefore, the effectiveness of the product has not been measured. To follow up on the results of the developed product, it is necessary to conduct research on its effectiveness.

\section{Materials and Methods}

This is a quasi-experimental study as the control group does not fully function to control external variables that influence the implementation of the experiment [19]. This is a Quasi Experimental research, where the experimental group and the control group were not taken randomly. Quasi Experiment uses the pretest-posttest group design [20].

Table 1. Design of Pretest-Postest Group

\begin{tabular}{|c|c|c|c|}
\hline Group & Pretest & Treatment & Posttest \\
\hline Control & P1 & T1 & P2 \\
\hline Experimental & P1 & T2 & P2 \\
\hline
\end{tabular}

P1: Initial ability

T2: Character Assessment Test

T1: Thematic learning using materials from an early class teacher

$\mathrm{T} 2$ : Thematic learning uses local wisdom-based textbooks.

The research was conducted from March to April. Subjects in this study were all grade 1 elementary schools consisting of class $1 \mathrm{~A}$ with 27 students and 1B class with 
26 students. For the experimental class were classes $1 \mathrm{~A}$ and control classes in class 1B. The research data analyzed were character assessment data before and after being given treatment in terms of the character aspects of cooperation from each class namely the experimental group and the control group. The statistical analysis technique used refers to testing the hypothesis. Based on the samples used, namely the control class and experimental class and each sample was given a different treatment, the form of the hypothesis in this study was comparative / comparative in two independent samples.

The used statistical analysis technique is for testing the hypothesis. Based on the samples used, the control class and experimental class were given different treatments, the comparative / comparative in two independent samples is the form of this hypothesis. The flow chart of statistical analysis for two independent samples is presented as follows [21].

The data collection technique used was observation. Observation sheets were used to identify the students' cooperation character during learning process before and after treatment. There were ten indicators of cooperation character in this study, namely [22]:

(A) Participating actively in group discussions

(B) Utilizing the time to discuss in groups well

(C) Receiving opinions from friends in discussions

(D) Helping group friends who feel difficult,

(E) Accepting decisions made by groups

(F) Creating an atmosphere that is familiar in group discussions

(G) Supporting friends who give good opinions

(H) Giving motivation to less active group members

(I) Being responsible for tasks that have been given in groups

(J) Conveying opinions or ideas to other group members in polite language.

Calculation of data analysis was performed using the SPSS version 21.0 application with a significance value of 0.05 and a confidence level of $95 \%$. Before testing the hypothesis using the $t$-test the prerequisite test is done first, namely the normality test and homogeneity test. The normality test is done to determine whether the data obtained comes from populations that are normally distributed or not. The normality test is carried out by the Kolmogrov-testSminov Z (K-S Z) used software SPSS version 21.0. The testing criteria, if the test value Kolmogorov-Smirnov or Sig. $>0.05$ then data is normally distributed, and if the value of Sig. $<0.05$, the data is not normal.

The homogeneity test was carried out to find out whether the two classes had homogeneous variances or not. The homogeneity test was carried out uniquely. To test the homogeneity of variance, Levene was carried out. Using $\alpha$ $=0.05$ hypothesis $\mathrm{H} 0=$ population has a homogeneous variance, $\mathrm{H} 1=$ population has a non-homogeneous variance. The testing criteria are if the significance value is $>$
0.05 then the null hypothesis is accepted. Testing the hypothesis with the aid of SPSS version 21.0 is an Independent Sample $\mathrm{T}$ test. The Independent Sample $\mathrm{T}$ test was used to test the significance of the differences in the mean of the two groups. This test is also used to test the effectiveness of thematic textbooks based on local wisdom on the character of student cooperation. Data is processed using SPSS 21.0, with the formulation of the problem as follows:

$\mathrm{H} 0=$ There is no effectiveness between the experimental class and the control group.

$\mathrm{H} 1=$ There is effectiveness between the experimental class and the control group.

The decision criterion is that $\mathrm{H} 0$ is rejected if $\mathrm{F}$ count $>\mathrm{F}$ table if (sig) $<\alpha=0.05$.

\section{Result and Discussion}

In the preliminary study, the researcher observed the two classes. Observation was conducted by looking at the character of students one by one by 5 observers during 14 effective days. Based on the results of observations, normality tests and homogeneity tests were conducted. The normality test was carried out in both groups to find out the sample data from populations whether normally distributed or not [23]. The results of the normality test calculation are as follows:

Table 2. Normality Test of Experimental and Control Group

\begin{tabular}{|c|c|c|}
\hline Group & Sig. & Conclusion \\
\hline Pretest of experimental group & 0,139 & Normal \\
\hline Pretest of control group & 0,433 & Normal \\
\hline
\end{tabular}

Based on the table above, it can be seen that the pre-test data on character evaluation of students in the experimental class and the control class has a sig value $>0.05$, it can be concluded that the two classes are normally distributed.

Homogeneity test was carried out through Lavene test. Based on the results of the homogeneity test calculation, it is found out that the pre-test count is 0.698 with a significant value of 0.407 . From these results, the significance value is greater than 0.05 so it is concluded that the data in this study have a homogeneous variance. Effectiveness test of the use of thematic textbooks based on local wisdom on the character of cooperation in grade 1 elementary school students was analyzed using the independent sample $\mathrm{T}$ test.

Table 3. Independent $\mathrm{T}$ test results

\begin{tabular}{|c|c|c|c|}
\hline Group & Average & F & Sig. \\
\cline { 1 - 2 } Experimental Group & 31,96 & \multirow{2}{*}{11,991} & \multirow{2}{*}{0,01} \\
\hline Control Group & 26,11 & & \\
\hline
\end{tabular}

Based on the average $t$ test of the experimental class post test was 31.96 and the average posttest $t$ test of the control 
class was 26.11, so it was concluded that the average rating of the experimental class characters was 5.85 greater than the control class. Based on the results of hypothesis testing produces Fcount of 11.991 with a significance value of 0.01 . From these results the value of the hypothesis test is smaller than 0.05 . Then it can be concluded that the null hypothesis (H0) is rejected or $(\mathrm{H} 1)$ is accepted. This proves that the use of thematic teaching materials based on local wisdom is effective on students' character of cooperation.

The character of cooperation in the control class and experimental class can also be proven by observation result looking at the comparison of each indicator of cooperation before and after treatment. The followings are the figures of the achievement of cooperation indicators before and after using thematic textbooks based on local wisdom.

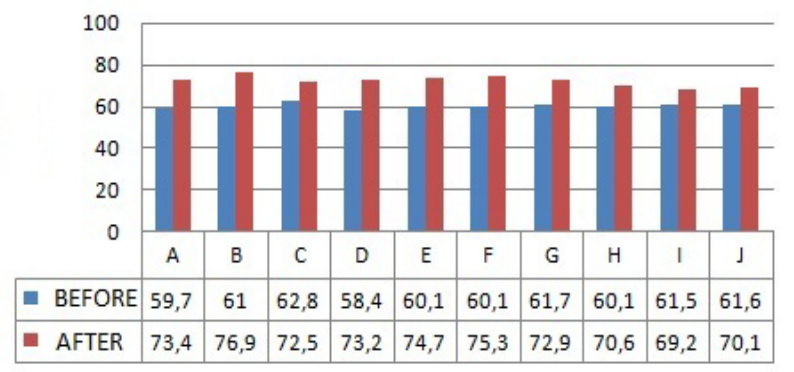

Figure 1. Comparison of Cooperation Character of Control Group

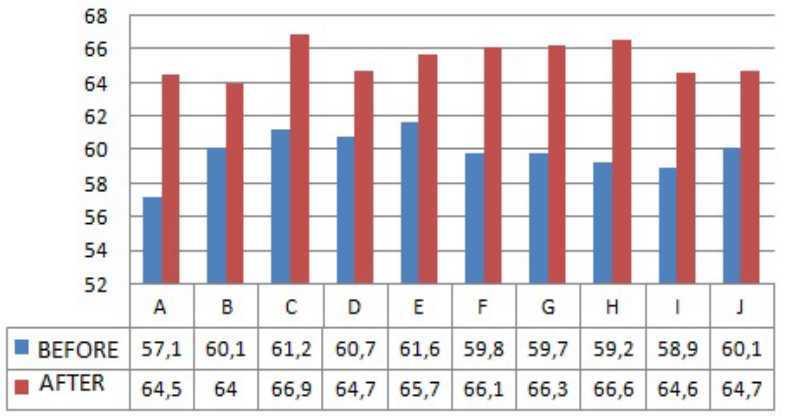

Figure 2. Comparison of Cooperation Character of Experimental Group

Based on figure 1, the cooperation character in the control group did not significantly increase before and after treatment. Whereas in Figure 2, it can be seen a significant increase before and after treatment. In the experimental group there is a fairly high increase in the cooperation character, namely the indicator (A) Participating actively in group discussions, (C) Receiving opinions from friends in discussions, (F) Creating an atmosphere that is familiar in group discussions, (G) Supporting friends who give good opinions, and $(\mathrm{H})$ Giving motivation to less active group members.

Based on the data that has been presented, there is a significant increase seen from the number of students who initially in the fair category into good categories, it can show that the application of teaching books is effective to improve students character of cooperation.

Local wisdom used in textbooks is taken from the values in the Yogyakarta region which include folk songs, traditional games, folk dances, traditional musical instruments and arts. One example of the type of local wisdom contained in the textbook is the game "Cublak-Cublak Suweng" which is accompanied by a song with the following lyrics.

cublak-cublak suweng suwenge ting gelenter mambu ketundung gudel pak empong lera-lere sopo ngguyu ndelikkake sir sir pong dhele gosong sir sir pong dhele gosong

Cublak Cublak Suweng is a game that is done in groups. This game begins with determining one child who will be assigned to find "suweng" or earrings in a group. It is usually appointed by "pingsut", a traditional fair choosing method between two people, almost similar to rock paper scissors. Generally, the earrings are replaced with other objects such as stones or pebbles. Children who are in charge of finding the pebble must lie face down, while other children who are not assigned sit in a circle around the assigned child by singing the cublak cublak suweng song while turning the pebble from one child's hand to another.

After the song is finished, the child who is lying face down gets up, while the other children pretend to hide the pebble in their right and left hands. The child's task is to find the pebble hidden by the other children. The game will continue if the child who is assigned cannot point correctly.

This is supported by the study conducted by Rukiyati and Purwastuti (2016, p.136) who examined the character education model based on local wisdom in elementary schools in Yogyakarta. The results showed that the game of cublak-cublak suweng enables children to be cooperative, honest, responsible, and brave. The cooperation value in the game of cublak cublak suweng is instilled by the way children learn to play their respective roles in keeping the suweng / earrings.

Character is a value that is internalized into a behavior because of habit, and it is also formed due to the influence of the environment. A person's character is manifested in the behavior that is formed due to custom where the person lives [25]. The implementation of thematic book based on local wisdom is not only effective on building students' character of cooperation, but it also gives students knowledge about local wisdom in their area. It can be proven that after implementation students were able to mention traditional games, songs, or dances. Character education should not be taught only in certain subjects. Instead, it should be instilled in all subjects by integrating learning and daily activities as all existing values are interrelated. Character is not a stand-alone subject, but must be integrated in children's learning and everyday life [26]. 


\section{Conclusions}

Cooperation is an attitude of wanting to do job together without discriminating other members in the group. Cooperation character is important for every student because it can train students to understand, feel, and carry out activities to achieve common goals. There are many ways to instill characters for elementary school students, one of which is by using thematic textbooks based on local wisdom. Using local wisdom-based book, students' characters become easier to build because it uses materials close to their lives. Based on the results of this study, textbooks based on local wisdom are proven to be able to improve students' character of cooperation. This can be seen from the score improvement in several indicators of cooperation such as participating actively in group discussions, receiving opinions from friends in discussions, creating an atmosphere that is familiar in group discussions, supporting friends who give good opinions, and giving motivation to less active group members. In addition, the textbook can also create learning more active and fun.

\section{Acknowledgments}

We would like to express our gratitude to primary school education program of Ahmad Dahlan University, for providing support to this research. We would also like to thank the ministry of research, technology, and higher education of Indonesia for funding this study through the PDP scheme.

\section{REFERENCES}

[1] Akmar \& Syarifuddin. Mengungkap Kearifan Lokal Sulawesi Selatan PPLH Regional Sulawesi, Maluku dan Papua, Kementerian Negara Lingkungan Hidup RI. Makassar: Masagena Press, 2007.

[2] Kamonthip \& Kongprasertamorn. Local Wisdom, Environmental Protection and Community Development: The Clam Farmers in Tambon Bangkhunsai, Phetchaburi Province, Thailand. MANUSYA: Journal of Humanities 10.1. 2007

[3] Tobroni. Pengembangan Pendidikan Karakter Bangsa Berbasis Kearifan Lokal. Jurnal Pendidikan Karakter Volume 14 Nomor 2 Juli - Desember. Malang: Universitas Muhammadiyah Malang, 2011.

[4] Warigan. Pengembangan Karakter Berbasis Kearifan Lokal Hamemayu Hayuning Bawana. Jurnal Pendidikan Karakter, tahun II, No.3, Oktober. Yogyakarta: UNY, 2012.

[5] Sudrajat, Ajat. Mengapa Pendidikan Karakter. Jurnal Karakter Tahun 1 Nomor 1 halaman 35-49, 2011.

[6] Wening, Sri. Pembentukan Karakter Bangsa Melalui Pendidikan Nilai. Jurnal Pendidikan Karakter Tahun II. No 1.
Hlmn 55-66. Yogyakarta: UNY, 2012.

[7] Pala, Aynur. The Need for Character Education. International Journal of Social Sciences and Humanity Studies. Vol 3, Nomor 2, 2011.

[8] Muttaqin, Raharjo \& Masturi. The Implementation Main Values of Character Education Reinforcement in Elementary School. Journal of Prima Education. Volume 7, Number 1, 2018.

[9] Dharma Kesuma, Cepi Triatna, \& Johar Permana. Pendidikan Karakter Kajian Teori dan Praktik di Sekolah. Bandung: Rosdakarya, 2011.

[10] Mulyasa. Menjadi Guru Profesional. Bandung: Rosdakarya, 2013.

[11] Agboola, Alex and Tsai, Kaun Chen. Bring Character Education into Classroom. Europan Journal of Educational Research. Vol 1, Nomor 2, 163-170, 2012.

[12] Rukiyati, et all. Penanaman Nilai Tanggung Jawab dan Kerja Sama Terintegrasi dalam Perkuliahan Ilmu Pendidikan. Jurnal Pendidikan volume IV (2) halaman 209-215, 2014.

[13] Kemdiknas. Rencana Strategis Kementrian Pendidikan Nasional 2010-2014. Jakarta: Kemdiknas, 2010.

[14] Kurniawan. Pengembangan Buku Siswa untuk Meningkatkan Proses dan Hasil Belajar Kompetensi Dasar Comflake Cookies pada Siswa Tunagrahita-Lb Negeri Gedangan Sidoarjo. Jurnal Boga Volume 2 (6-17), 2013.

[15] Rachmadyanti, Putri. Penguatan Pendidikan Karakter bagi Siswa Sekolah Dasar Melalui Kearifan Lokal. Jurnal JPSD. Vol 3. No 2. Halm 201-214. Yogyakarta: UAD, 2017.

[16] Sukini. Pembelajaran Tematik di Sekolah Dasar Kelas Rendah dan Pelaksanaannya. Jurnal Magistra No. 82 Th. XXIV Desember. Klaten, 2012.

[17] Trianto. Mendesain Model Pembelajaran Inovatif, Progesif, Konsep, Landasan dan Implementasinya Pada Kurikulum Tingkat Satuan Pendidikan. Jakarta: Prenada Media Group, 2013.

[18] Prasetyo, Zuhdan Kun., dan Junaidi. Pengaruh Subject Specific Pedagogy Tematik Terhadap Karakter Hormat dan Tanggung Jawab Pada Siswa Kelas III Sekolah Dasar. Jurnal Pendidikan Karakter. Tahun V. Nomer.1 hal.34, 2015.

[19] Sugiyono. Metode Penelitian dan Pengembangan. Bandung: Alfabeta, 2015.

[20] Creswell, John W. Research Design Pendekatan Kualitatif, Kuantitatif dan Mix (Terjemahan Achmad Fawaid). Yogyakarta: Pustaka Pelajar, 2010.

[21] Lestari, et.all. Penelitian Pendidikan Matematika. Bandung: Refika Aditama, 2015.

[22] Pranowo. Implementasi Pendidikan Karakter Kepedulian dan Kerja Sama Pada Mata Kuliah Keterampilan Berbicara Bahasa Prancis Dengan Metode Bermain Peran. Jurnal Pendidikan Karakter.FBS Universitas Negeri Yogyakarta Volume 3, Nomor 2, Halaman 225, 2013.

[23] Gujarati, Damodar. Basic Econometrics (Ekonomika Dasar) 
Alih bahasa SumarnoZain. Jakarta: Erlangga, 2004.

[24] Rukiyati and L. Andriyani P. Model Pendidikan Karkater Berbasis Kearifan Lokal pada Sekolah Dasar di Bantul Yogyakarta. Jurnal Pendidikan Karakter. 2016.

[25] Samani, Muchlas, \& Hariyanto. Konsep dan Model
Pendidikan Karakter. Bandung: Remaja Rosdakarya, 2017.

[26] Judiani, Sri. Implementasi Pendidikan Karakter di Sekolah Dasar melalui Penguatan Pelaksanaan Kurikulum. Jurnal Pendidikan dan Kebudayaan, Vol.16, 3, 280-289, 2010. 